\title{
Operating Cash Flows, Cash Recovery Rates And Internal Rates Of Return
}

\author{
Christine Andrews, Florida Gulf Coast University, USA \\ Joseph C. Rue, Florida Gulf Coast University, USA \\ Ara Volkan, Florida Gulf Coast University, USA
}

\begin{abstract}
Investors depend on financial reporting to assess the amounts and timing of future cash flows. Unfortunately, the historical cost basis may not provide sufficient information to judge future cash flows. The Financial Accounting Standards Board argues that the market price of common stock incorporates the market estimate of discounted future cash flows. This paper illustrates the calculation of operating cash flow on a per share (CFPS) basis and measures a firm's internal rate of return by dividing the CFPS by the beginning of the year stock price reported by the Dow Jones Industrials. Although this measure may be affected by other market events, we believe it has potential information content and may provide investors with a tool to value stocks.
\end{abstract}

Keywords: Cash recovery rate, forecasting cash flows, operating cash flows, internal rate of return

\section{INTRODUCTION}

ऽ

tatement of Financial Accounting Concepts (SFAC) No. 1, Objectives of Financial Reporting by Business Enterprises, stresses that financial reporting should provide information to help investors and creditors in assessing the amounts, timing, and uncertainty of current and future cash flows (FASB, 1978). In addition, the Financial Accounting Standards Board (FASB) has argued that the market price of common stock incorporates the market estimate of the discounted future cash flows to the firm (FASB, 2000) which are dependent upon the ability of the firm to generate cash. Thus, there is a direct link between an investor's rate of return on an investment in common stock and the firm's cash flows. Consequently, financial statement users are interested in determining the cash flows for the period and attempt to predict future cash flows of a firm. Unfortunately, the historical cost basis of financial reporting may not provide enough information to assess current cash flows and to predict future cash flows.

The accounting rate of return (ARR) is commonly used to evaluate a firm's profitability. The ARR, which is the ratio of a firm's net income to its net assets, is used primarily because it is easy to compute and understand. However, the ARR ignores the cash generating ability of the firm and the market value of the firm's assets. A better measure would be the cash-flow based internal rate of return (IRR). The IRR can be defined as the true investment yield of an investment project over its useful life and is the cash rate at which the discounted present value of future cash flows is equal to the current cost of an investment. A number of studies have attempted to estimate IRRs of companies from published financial statements (Luckett, 1986; Steele, 1986). In spite of these efforts, the computation of firm-specific IRRs by external parties has proven difficult if not impossible to accomplish. Thus, the use of accrual accounting based profitability measures (e.g., ARRs) are justified since cash-flow based surrogates for IRR and other alternative profitability measures are not readily available.

\section{PURPOSE}

This study reports a methodology for determining IRRs untainted by the choice of accounting techniques and using information already available in financial statements. It is hoped that using this measure will result in improved forecasts of future cash flows and stock prices. 


\section{MARKET VALUATION OF FIRMS}

A measure of the value of a firm is the present value of the net cash inflows that will accrue from its net assets through operations and/or liquidation. Research in accounting, economics, and finance has consistently shown that discounted net cash flow information is essential to the efficient functioning of capital markets (Fama, 1970). Capital resources are best allocated when investors and creditors can accurately estimate the future net cash flows and the discount rates specific to an individual or group of firms.

The management of a firm has access to a wealth of information when making investment decisions. Internal investment decisions are generally based upon the ability of a project to generate sufficient cash flows to provide at least a minimum rate of return. Given a choice among alternative projects that exceed this minimum or hurdle rate, management will select projects with the highest return. It is, therefore, perfectly logical to assume that investors and creditors, who view the firm as the aggregate of its projects, would also need similar information on internal rate of return and cash flows in order to value the firm as a whole.

The major source of communication of firm specific internal information to external users is the financial statements published annually. The measurement and reporting rules for the contents of financial statements are determined by the accounting profession. The FASB has, on many occasions, indicated that the financial reports should provide information on cash flows. In spite of all these activities in the area of cash flow reporting, the FASB and a substantial majority of accountants still believe that income and profit information should be the main focus of financial reporting (Ball \& Brown, 1968; Beaver, 1968; Sprouse, 1978).

The accounting rule-making bodies continue to emphasize the constructs of accrual accounting as the primary basis of accounting standards and reports. Thus, a paradoxical situation emerges in the financial reporting area. On the one hand, the FASB recognizes that, at least in part, the security values and stock prices may be regarded as the discounted amount of expected future cash flows of a firm. Therefore, the FASB advocates reports that will enable the forecasters to assess the amounts, timing, and uncertainty of a firm's future cash generation. On the other hand, the FASB requires that audited financial statements be prepared using accruals and historical cost information and give prominence to income measures. As a result, the amounts in financial reports are influenced by choices in accounting methods (e.g., depreciation and inventory valuation methods) and are not as useful in obtaining information about past and future cash flows.

It is impossible to obtain the cash flow information on the firm's individual projects and the firm specific discount rate using current financial reports. Consequently, financial analysts are forced to settle for deficient but readily available surrogates of cash flows and IRR such as the accounting return on investment (i.e., net income divided by net assets) and ARR. Users of accounting information need measures of cash flows and IRRs which are based on data items published in the financial statements, do not require knowledge of cash flows from the firm's individual projects, and are independent of choices in accounting methods.

\section{CASH RECOVERY RATES}

To address the problem of finding appropriate surrogates for IRR and cash flows, Ijiri developed the concept of cash recovery rates (CRR). Ijiri (1978) defined CRR as the ratio of the sum of funds from operations, proceeds from disposal of long-term assets, interest expense and the decrease in current assets and the average of beginning and ending gross total assets. He found that if certain conditions related to the average life of fixed assets, the size of the firm, and the stability of CRRs were true, the CRRs could be used to approximate the IRR of a firm. Ijiri asserts that investors need to have information on cash generated (recovered) by all of the firm's projects in order to predict the firm specific IRR. Knowledge of cash flow patterns of the firm's individual projects is not necessary. The recovery rate represented the reciprocal of the payback period, and allowed one to measure the IRR of a firm's portfolio of investments.

Several studies have shown that most large and mature firms display stable CRRs over time (Ijiri, 1978; Volkan and Rue, 1987, 1991). The existence of some degree of stability may be desirable, since it may be assumed that managers of successful firms try to achieve at least the overall return rate originally used by them as a bench- 
mark for investment decisions. Thus, individuals computing CRRs may assume that at the very least, the stability assumption holds for large and mature firms. A stable CRR implies that a firm or a division of a firm can be viewed as one investment without regard to the cash flow profiles and useful lives of individual projects. When CRRs are stable, it is possible to assume that increases (growth) in investments, whether in real or nominal terms, are managed along with growth in cash recoveries so as to maintain or increase the CRR. Mathematically, it can be shown that under such conditions one can equate the CRR to the firms profitability, that is CRR = IRR.

Rue and Volkan (1991) further tested the stability of CRR in a study of 1200 firms. The results of their study reveal an unmistakable pattern of conformity with the model developed by Ijiri. Large firms tended to exhibit stable CRRs. Firms lacking one or more of his model's assumptions had unstable CRRs over time. Thus, the CRR measure may be useful for firms conforming with Ijiri's assumptions but less useful for the firms which do not conform.

\section{A DIFFERENT APPROACH}

The CRR tool developed by Ijiri (1978) depends on many assumptions which may limit its usefulness. A better approach to approximating the cash flow IRRs would be to compute the ratio of the annual cash generated by a firm to the market value of the firm's net assets as of the beginning of the year. This would represent the cash return on the beginning of the year investment. If a firm has a minimum cost of capital return level which it expects to receive on all investments, it should only be investing in projects which will meet or exceed this level. If a firm does not meet this target return in a given year, the firm can sell/buy assets and invest in new/old projects which it believes will return the desired rate. A given portfolio of projects can change over time to achieve the desired return rate. Investors and creditors desire to have information about a firm's ability to achieve and surpass targeted return levels. Financial statements provide information about operating cash flows and information about investments in assets and sale of assets in the statement of cash flows.

\section{Approximating the Fair Value of a Firm's Net Assets}

To determine a cash flow return rate for a year and to measure the trend in the cash flow rate over time, investors need a surrogate for the market value of a firm's net assets. In theory, a stock price at any point in time represents the present value of a firm's future cash flows at an appropriate discounted rate of interest (Fama, 1970). This firm specific discount rate includes a risk free rate and a risk premium rate. The risk premium rate is a function of the variability of the firm's future cash flows. High levels of variability increase the rate. Low levels of variability reduce the risk premium and thus increase the market price of the stock.

The market value of a firm's net assets is a function of the ability of the invested assets to generate future cash flows. Higher future cash flows result in higher asset values. Lower future cash flows result in lower asset values. In addition, stable future cash flows should reduce the risk premium and further increase the value of the firm's assets. Thus, there is a direct relationship between the value of a firm's net assets and the value of a firm's stock price which allows us to use the stock price as a surrogate for the market value of the firm's net assets on a per share basis.

\section{Approximating Cash Based IRRs}

We determine operating cash flows per share by dividing operating cash flows by the average number of shares outstanding. This is the same variable similar to the one used in determining earnings per share. We approximate a per share cash flow IRR for each year by dividing cash flow per share (CFPS) by the beginning of the year market price (MP) of the stock. Thus,

$\mathrm{CFPS} / \mathrm{MP}=\mathrm{IRR}$ for a given year 


\section{METHODOLOGY}

We selected 30 firms listed on the Dow Jones Industrial Average to demonstrate how one could measure specific cash flow IRRs over a six year period (2003-2008). Previously, Ijiri (1978) found that the CRRs for this group of firms were stable. We wanted to see if this held true for our measure of IRR as well. Operating cash flow, stock price, weighted average shares of common stock outstanding, and net income were retrieved from Yahoo! Finance and Mergent Online (2009). SBC Communications and AT\&T were dropped from the sample because they merged in 2005. A total of 31 firms were included from the 2003-2008 time period because of changes in the composition of the Dow Jones Industrials.

\section{RESULTS}

\section{Operating Cash Flows}

A visual analysis of Table 1 illustrates relatively stable and increasing total operating cash flows for most of the Dow Jones 30 companies. Other than a few outliers including AIG, General Motors, JP Morgan and Citigroup, the majority of these firms have relatively stable and generally increasing cash flows over the period of 2003-2008. This is consistent with Ijiri (1978) who found that large, mature firms display stable cash return rates over time.

Table 1: Operating Cash Flows for Dow Jones Industrials 2003 - 2008

\begin{tabular}{|c|c|c|c|c|c|c|c|}
\hline CIK & Firm & 2003 & 2004 & 2005 & 2006 & 2007 & 2008 \\
\hline AA & Alcoa & $\$ \quad 2,430$ & 2,199 & 1,676 & 2,567 & 3,111 & 1,234 \\
\hline AIG & AIG & 36,155 & 35,581 & 25,138 & 6,829 & 35,171 & 755 \\
\hline AXP & American Express & 2,538 & 9,143 & 8,045 & 9,005 & 8,484 & 8,666 \\
\hline BA & Boeing Aircraft & 3,881 & 3,458 & 7,000 & 7,499 & 9,584 & (401) \\
\hline C & Citigroup & $(14,854)$ & $(2,404)$ & 31,799 & 13 & $(71,430)$ & 96,143 \\
\hline CAT & Caterpillar & 2,066 & $(3,991)$ & 3,113 & 5,799 & 7,935 & 4,787 \\
\hline DD & DuPont & 2,589 & 3,231 & 2,542 & 3,736 & 4,290 & 3,129 \\
\hline DIS & Disney & 2,901 & 4,370 & 4,269 & 6,058 & 5,421 & 5,446 \\
\hline EK & Eastman Kodak & 1,645 & 1,168 & 1,208 & 956 & 314 & 153 \\
\hline GE & General Electric & 30,289 & 36,484 & 37,641 & 30,646 & 45,967 & 48,601 \\
\hline GM & General Motors & 7,875 & 9,356 & $(16,856)$ & $(11,759)$ & 7,731 & $(12,065)$ \\
\hline HD & Home Depot & 4,802 & 6,545 & 6,904 & 6,484 & 7,661 & 5,727 \\
\hline HON & Honeywell & 2,199 & 2,253 & 2,442 & 3,211 & 3,911 & 3,791 \\
\hline $\mathrm{HPQ}$ & Hewlett-Packard & 6,057 & 5,088 & 8,028 & 11,353 & 9,615 & 14,591 \\
\hline IBM & IBM & 14,407 & 15,323 & 14,874 & 15,006 & 16,008 & 18,812 \\
\hline INTC & Intel & 11,515 & 13,119 & 14,823 & 10,620 & 12,625 & 10,926 \\
\hline IP & International Paper & 1,822 & 2,388 & 1,510 & 1,223 & 1,887 & 2,669 \\
\hline JNJ & Johnson Johnson & 10,595 & 11,131 & 11,877 & 14,248 & 15,249 & 14,972 \\
\hline JPM & JP Morgan Chase & 14,601 & $(21,805)$ & $(30,236)$ & $(49,579)$ & $(110,560)$ & 23,098 \\
\hline KO & Coca-Cola & 5,456 & 5,968 & 6,423 & 5,957 & 7,150 & 7,571 \\
\hline $\mathrm{MCD}$ & McDonald's & 3,269 & 3,904 & 4,337 & 4,341 & 4,876 & 5,917 \\
\hline MMM & $3 \mathrm{M}$ & 3,773 & 4,282 & 4,258 & 3,839 & 4,276 & 4,533 \\
\hline MO & Altria & 10,816 & 10,890 & 11,060 & 13,586 & 10,316 & 4,881 \\
\hline MRK & Merck & 9,862 & 8,799 & 7,609 & 6,765 & 6,999 & 6,572 \\
\hline MSFT & Microsoft & 15,797 & 14,626 & 16,605 & 14,404 & 17,796 & 21,612 \\
\hline PFE & Pfizer & 11,739 & 16,340 & 14,733 & 17,594 & 13,353 & 18,238 \\
\hline PG & Procter Gamble & 8,700 & 9,355 & 8,679 & 11,375 & 13,410 & 15,008 \\
\hline UTX & United Technologies & 948 & 993 & 991 & 980 & 964 & 938 \\
\hline VZ & Verizon & 22,482 & 21,820 & 22,012 & 24,106 & 25,739 & 26,620 \\
\hline WMT & Wal-Mart & 15,996 & 15,044 & 17,633 & 20,164 & 20,354 & 23,147 \\
\hline XOM & Exxon Mobil & 28,498 & 40,551 & 48,138 & 49,286 & 52,002 & 59,725 \\
\hline
\end{tabular}


Figure 1 presents operating cash flows for the sample for the years 2003-2008. Again, with the exception of the outliers identified previously, the operating cash flows are relatively stable and generally increasing. Removing the outliers provides a better view of the distribution of the cash flows, revealing consistent operating cash flows. It is important to remember that these results do not include accruals or other adjustments but simply reflect cash from operating activities.

Figure 1: Dow Jones Industrials without Outliers Operating Cash Flows 2003-2008

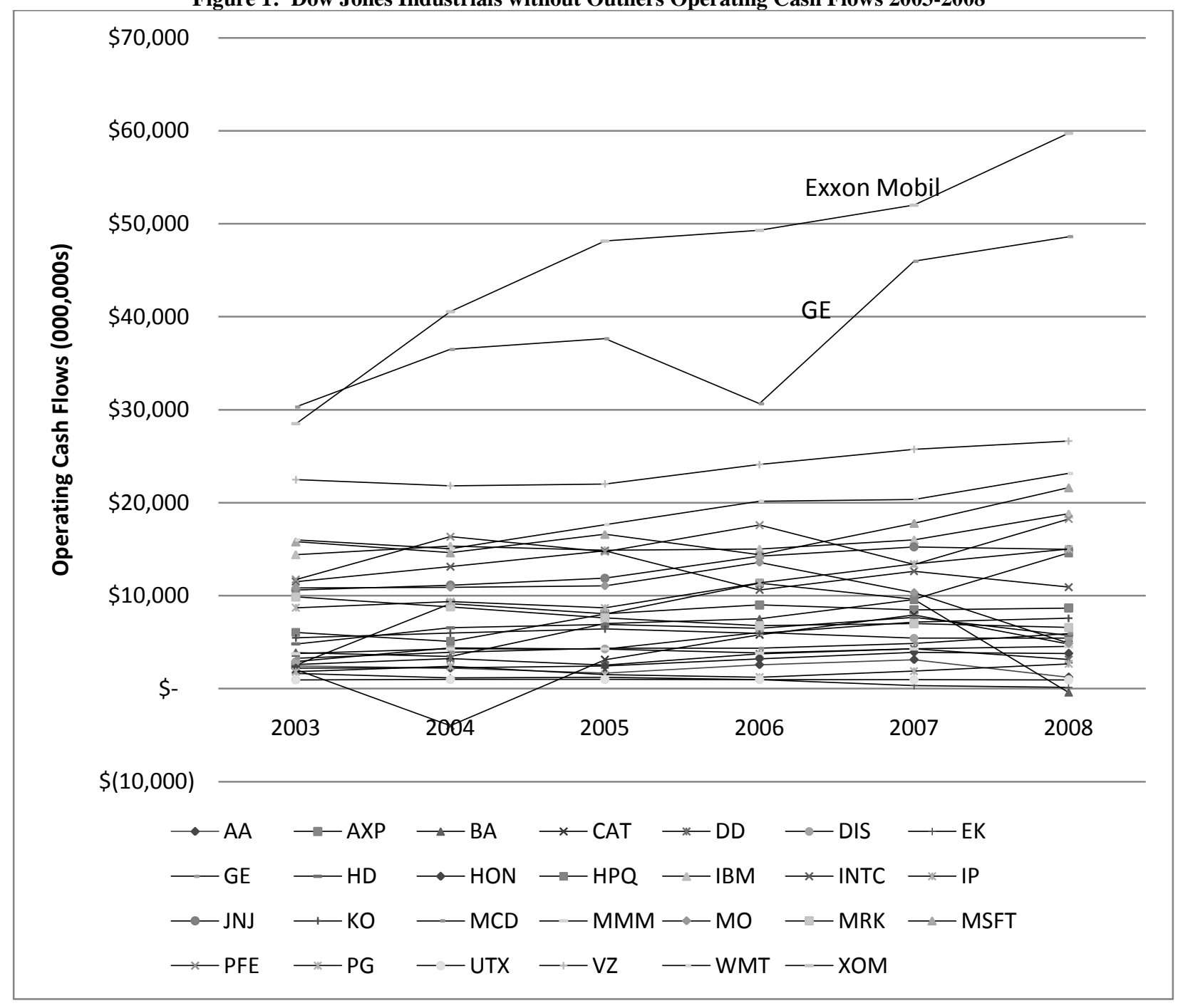

Next, we order the firms by degree of capital intensity by grouping firms using fixed assets as a percentage of total assets. Those firms whose fixed assets comprise more than $25 \%$ of total assets (11 high capital intensity firms) and of those firms whose fixed assets comprise less than $15 \%$ of total assets (9 low capital intensity firms) are compared. Exxon Mobil was removed from the $>25 \%$ sample as an outlier due to extraordinarily high cash flows. The visual analysis of figures 2 and 3 further supports Ijiri's (1978) premise that large firms have stable cash return rates. The majority of firms with high capital intensity with fixed assets comprising $>25 \%$ of total assets are clustered between $\$ 2.5$ and $\$ 10$ billion in operating cash flows. The firms that have less capital intensity with fixed assets totaling $<15 \%$ of total assets show greater variation in operating cash flows with a range of $\$ 2.5-\$ 25$ billion. Of the less capital intensity firms, Microsoft, IBM, Pfizer, and Proctor and Gamble have operating cash flows exceeding \$15 billion. 
Figure 2: Dow Jones Industrials Operating Cash Flows for Firms with Fixed Assets $>25 \%$ of Total Assets

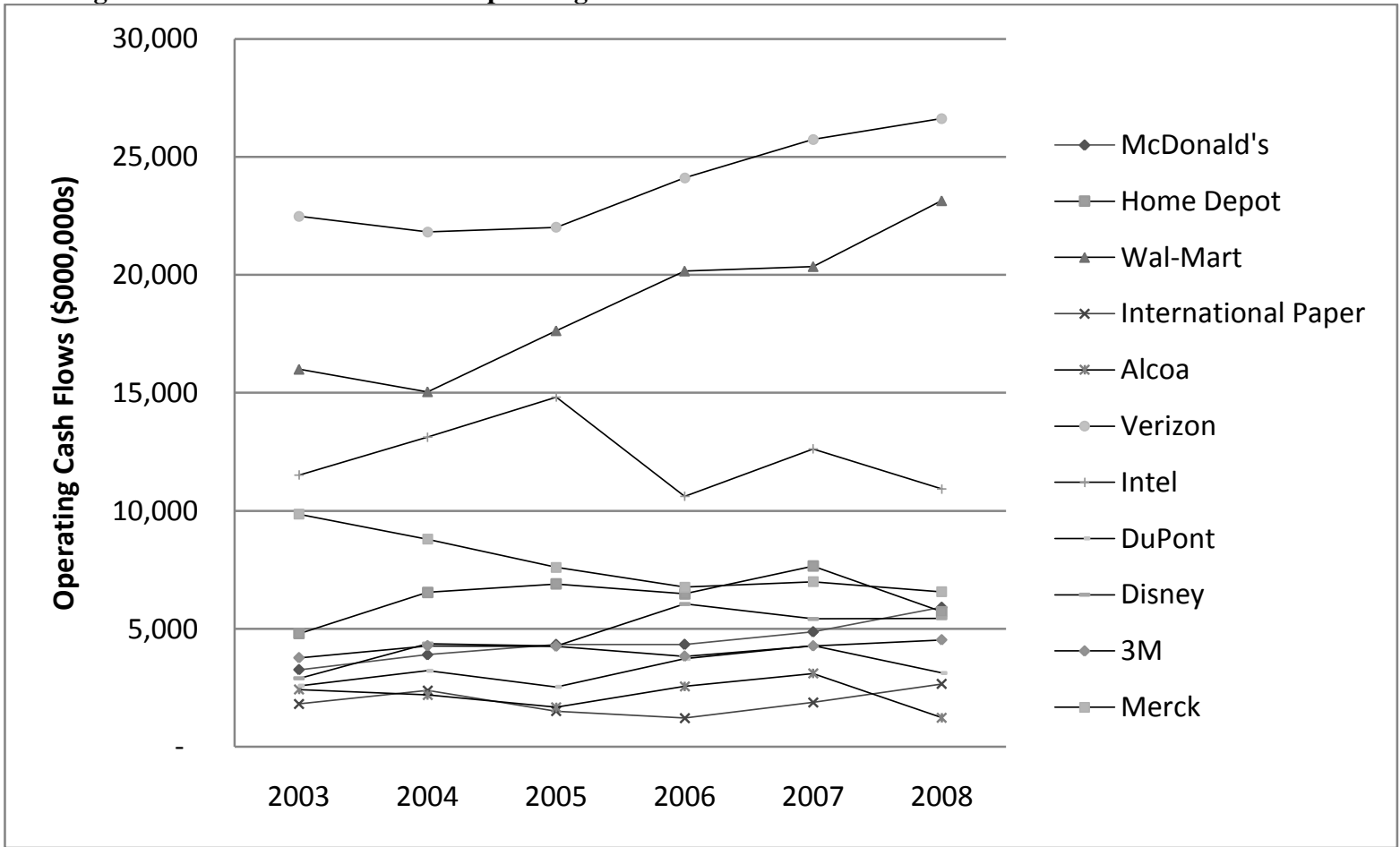

Figure 3: Dow Jones Industrials Operating Cash Flows for Firms with Fixed Assets < 15\% of Total Assets

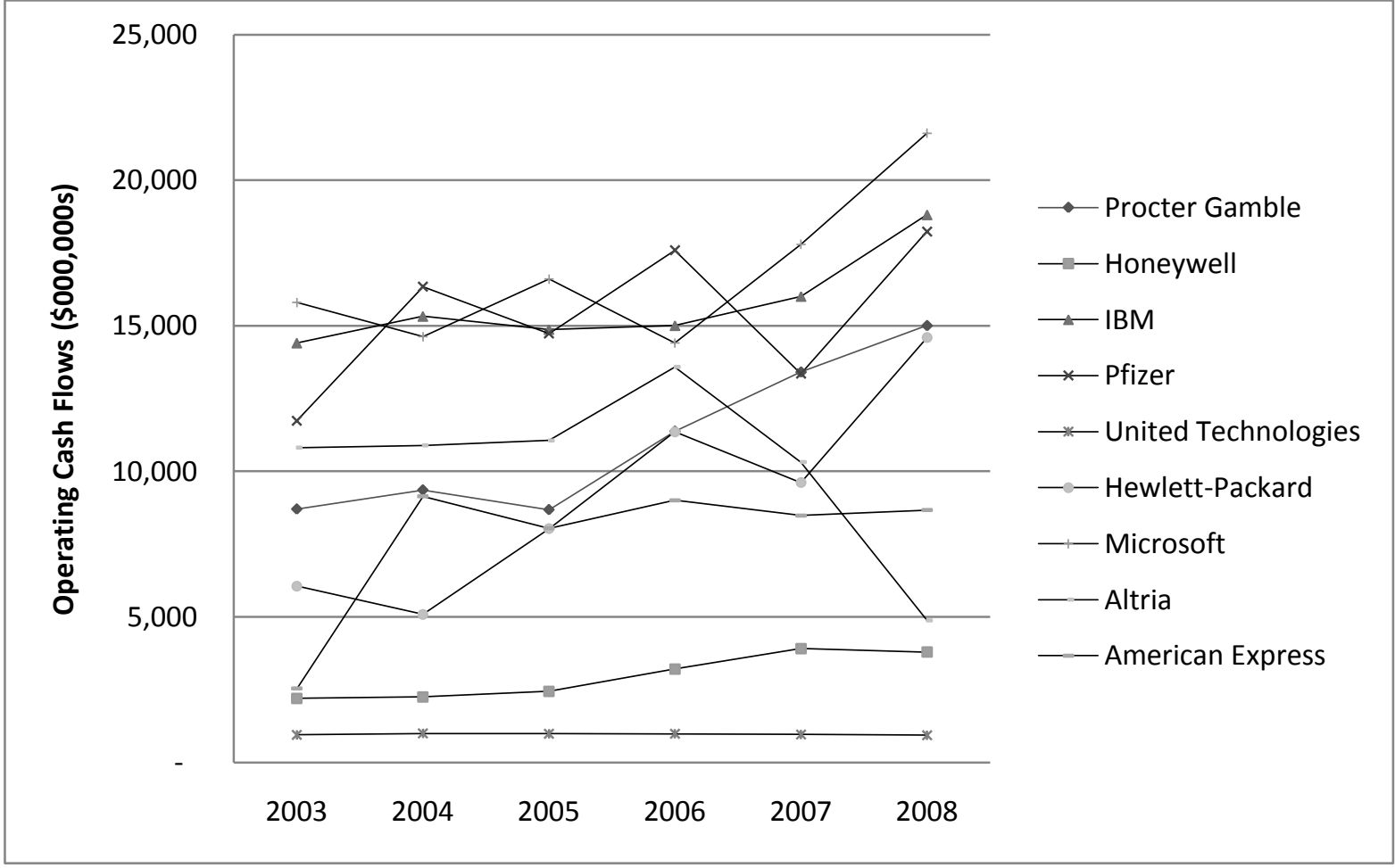




\section{Cash Flow Based IRRs}

In order to calculate a cash flow IRR for Dow Jones Industrials, we first divided operating cash flows by the weighted average of common shares outstanding to obtain cash flow per common share. Next, using the stock price at the beginning of each period as a proxy for firm's market value per share, we divided the cash flow per common share for the year by the beginning of period stock price. Table 2 summarizes these results. A review of this table reveals more variation as compared to the operating cash flows in Table 1, yet we still show some degree of relatively consistent returns for some of the firms over most years.

Table 2: Operating Cash Flow per Share divided by Stock Price at Beginning of Period

\begin{tabular}{|c|c|c|c|c|c|c|c|}
\hline GK & Firm & 2003 & 2004 & 2005 & 2006 & 2007 & 2008 \\
\hline AA & Alcoa & $12.5 \%$ & $6.7 \%$ & $6.1 \%$ & $10.0 \%$ & $12.0 \%$ & $4.2 \%$ \\
\hline AlG & AIG & $23.9 \%$ & $20.6 \%$ & $14.7 \%$ & $3.8 \%$ & $19.0 \%$ & $0.5 \%$ \\
\hline AXP & American Express & $5.6 \%$ & $15.1 \%$ & $11.6 \%$ & $14.4 \%$ & $11.9 \%$ & $14.4 \%$ \\
\hline BA & Boeing Aircraft & $14.7 \%$ & $10.3 \%$ & $17.3 \%$ & $13.9 \%$ & $14.2 \%$ & $-0.6 \%$ \\
\hline $\mathrm{C}$ & Citigroup & $-8.3 \%$ & $-1.0 \%$ & $13.0 \%$ & $0.0 \%$ & $-26.1 \%$ & $62.0 \%$ \\
\hline CAT & Caterpillar & $13.1 \%$ & $-14.0 \%$ & $9.4 \%$ & $15.2 \%$ & $20.3 \%$ & $10.8 \%$ \\
\hline DD & DuPont & $6.1 \%$ & $7.1 \%$ & $8.2 \%$ & $9.5 \%$ & $9.6 \%$ & $7.9 \%$ \\
\hline DIS & Disney & $8.7 \%$ & $9.1 \%$ & $7.6 \%$ & $12.6 \%$ & $7.9 \%$ & $8.9 \%$ \\
\hline EK & Eastman Kodak & $16.4 \%$ & $15.9 \%$ & $13.0 \%$ & $14.2 \%$ & $4.2 \%$ & $2.5 \%$ \\
\hline GE & GE & $12.4 \%$ & $11.3 \%$ & $9.8 \%$ & $8.2 \%$ & $12.1 \%$ & $13.0 \%$ \\
\hline GM & General Motors & $38.1 \%$ & $31.0 \%$ & $-74.5 \%$ & $-107.0 \%$ & $44.5 \%$ & $-83.7 \%$ \\
\hline HD & Home Depot & $8.8 \%$ & $8.4 \%$ & $7.6 \%$ & $7.8 \%$ & $10.3 \%$ & $12.6 \%$ \\
\hline $\mathrm{HON}$ & Honeywell & $10.6 \%$ & $7.8 \%$ & $8.1 \%$ & $10.5 \%$ & $11.3 \%$ & $8.4 \%$ \\
\hline $\mathrm{HPQ}$ & Hewlett Parkard & $11.5 \%$ & $7.3 \%$ & $13.3 \%$ & $14.3 \%$ & $8.9 \%$ & $11.6 \%$ \\
\hline IBM & IBM & $10.8 \%$ & $9.9 \%$ & $9.4 \%$ & $11.9 \%$ & $11.6 \%$ & $12.8 \%$ \\
\hline INTC & Intel & $11.3 \%$ & $6.4 \%$ & $10.4 \%$ & $7.3 \%$ & $10.7 \%$ & $7.2 \%$ \\
\hline IP & International Paper & $10.9 \%$ & $11.4 \%$ & $7.4 \%$ & $7.6 \%$ & $12.9 \%$ & $19.6 \%$ \\
\hline $\mathrm{JNJ}$ & Johnson \& Johnson & $6.6 \%$ & $7.3 \%$ & $6.3 \%$ & $8.1 \%$ & $8.0 \%$ & $8.0 \%$ \\
\hline JPM & JP Morgan & $30.3 \%$ & $-21.2 \%$ & $-22.2 \%$ & $-36.0 \%$ & $-67.2 \%$ & $15.1 \%$ \\
\hline KO & Coca Cola & $5.1 \%$ & $4.8 \%$ & $6.4 \%$ & $6.3 \%$ & $6.4 \%$ & $5.3 \%$ \\
\hline $\mathrm{MCD}$ & McDonalds & $16.0 \%$ & $12.5 \%$ & $10.7 \%$ & $10.4 \%$ & $9.3 \%$ & $8.9 \%$ \\
\hline MMM & $3 \mathrm{M}$ & $7.8 \%$ & $6.5 \%$ & $6.8 \%$ & $6.6 \%$ & $7.6 \%$ & $7.7 \%$ \\
\hline MO & Philip Morris & $13.2 \%$ & $9.8 \%$ & $8.7 \%$ & $8.7 \%$ & $5.7 \%$ & $3.1 \%$ \\
\hline MRK & Merck & $7.8 \%$ & $8.6 \%$ & $10.8 \%$ & $9.8 \%$ & $7.4 \%$ & $5.3 \%$ \\
\hline MSFT & Microsoft & $5.7 \%$ & $4.9 \%$ & $5.7 \%$ & $5.3 \%$ & $6.1 \%$ & $6.5 \%$ \\
\hline PFE & Pfiser & $5.3 \%$ & $6.1 \%$ & $7.4 \%$ & $10.4 \%$ & $7.5 \%$ & $11.9 \%$ \\
\hline PG & Proctor \& Gamble & $7.8 \%$ & $7.3 \%$ & $6.3 \%$ & $6.4 \%$ & $6.6 \%$ & $6.6 \%$ \\
\hline UTX & United Technologies & $3.2 \%$ & $2.1 \%$ & $1.9 \%$ & $1.8 \%$ & $1.6 \%$ & $1.3 \%$ \\
\hline VZ & Verizon & $21.1 \%$ & $22.5 \%$ & $19.6 \%$ & $27.5 \%$ & $23.8 \%$ & $21.4 \%$ \\
\hline WMT & WalMart & $7.3 \%$ & $6.7 \%$ & $8.0 \%$ & $10.3 \%$ & $10.8 \%$ & $12.4 \%$ \\
\hline XOM & Exxon Mobil & $12.3 \%$ & $15.3 \%$ & $15.0 \%$ & $14.8 \%$ & $12.3 \%$ & $12.4 \%$ \\
\hline
\end{tabular}

Figure 4 presents operating cash flow per share as a percentage of stock price (IRR). Since the outliers compress the distribution, the graph presents the data excluding them (GM, JP Morgan, Caterpillar and Citigroup). It is interesting to compare Figure 1 with Figure 4. The relatively stable cash flows in Figure 1 are in contrast to the more variable IRR depicted in Figure 4. The stock price component of the IRR signals market risk, and the risk is reflected in Figurec 4. The measure indicates firm IRRs generally fall between $5 \%$ and $15 \%$, with United Technologies (including Carrier Air conditioning, Pratt \& Whitney aerospace systems.) approximating the low of 3\% return and Altria (Philip Morris) exhibiting above average returns. 
Figure 4: Operating Cash Flows divided by Beginning of Period Stock Price without Outliers

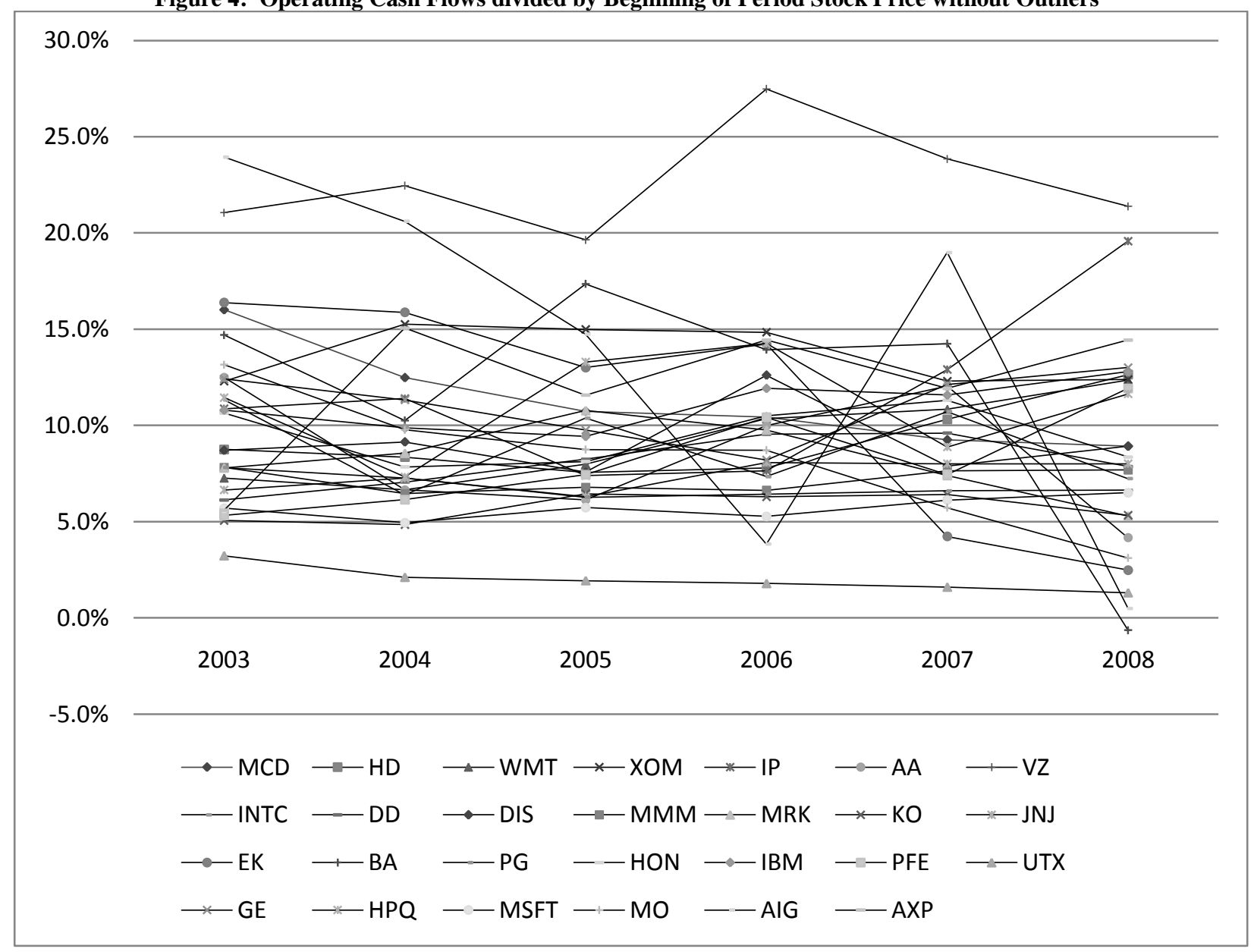

Dividing the sample firms between capital-intensive firms (fixed assets $>25 \%$ of total assets) and noncapital intensive firms (fixed assets $<15 \%$ of total assets) resulted in little difference in firm IRRs as illustrated in figures 5 and 6 . The IRR for both sets of firms ranges between $5 \%$ and $15 \%$ and displays little difference in stability, unlike the operating cash flow comparison for the same groups, which displayed overall higher cash flows for non-capital intensive industries. These differences may be due to industry membership.

\section{SUMMARY AND CONCLUSIONS}

The purpose of this study was to explore methods to approximate a cash flow IRR using the operating cash generation of a firm and the market value of the firm's net assets as of the beginning of the year. We selected the Dow Jones Industrial Average of 30 firms over a five year period from 2003 to 2008, using stock price per share at the beginning of each year as a proxy for the market value of the firm's net assets and operating cash flows per share. We found that operating cash flows for the sample were relatively stable, generally increasing, and ranged between $\$ 2.5$ and $\$ 20$ billion. Grouping the firms by fixed assets as a percent of total assets to explore if capital intensity had any effect, we found that operating cash flows of capital intense firms clustered between $\$ 2.5$ and $\$ 10$ billion whereas operating cash flows of less capital intense firms ranged from $\$ 2.5$ to $\$ 20$ billion, showing greater variation. Our review of operating cash flow per share divided by stock price at the beginning of the period showed greater variability overall than operating cash flows. We attribute this finding to the stock price component of the measure, which signals market risk. Finally, we found little difference in this measure based on capital intensity. 
Our measure of cash based IRR is easier to compute than Ijiri's CRR. In addition, our measure does not rely on assumptions concerning the lives of fixed assets, stability of the ratios, and firm size. However, our measure shows more variability than the CRRs and may be a less reliable estimate of a firm's true discount rate.

Figure 5: Operating Cash Flows Divided by Beginning of Period Stock Price where for Firms with Fixed Assets $>25 \%$ of Total Assets (without outliers)

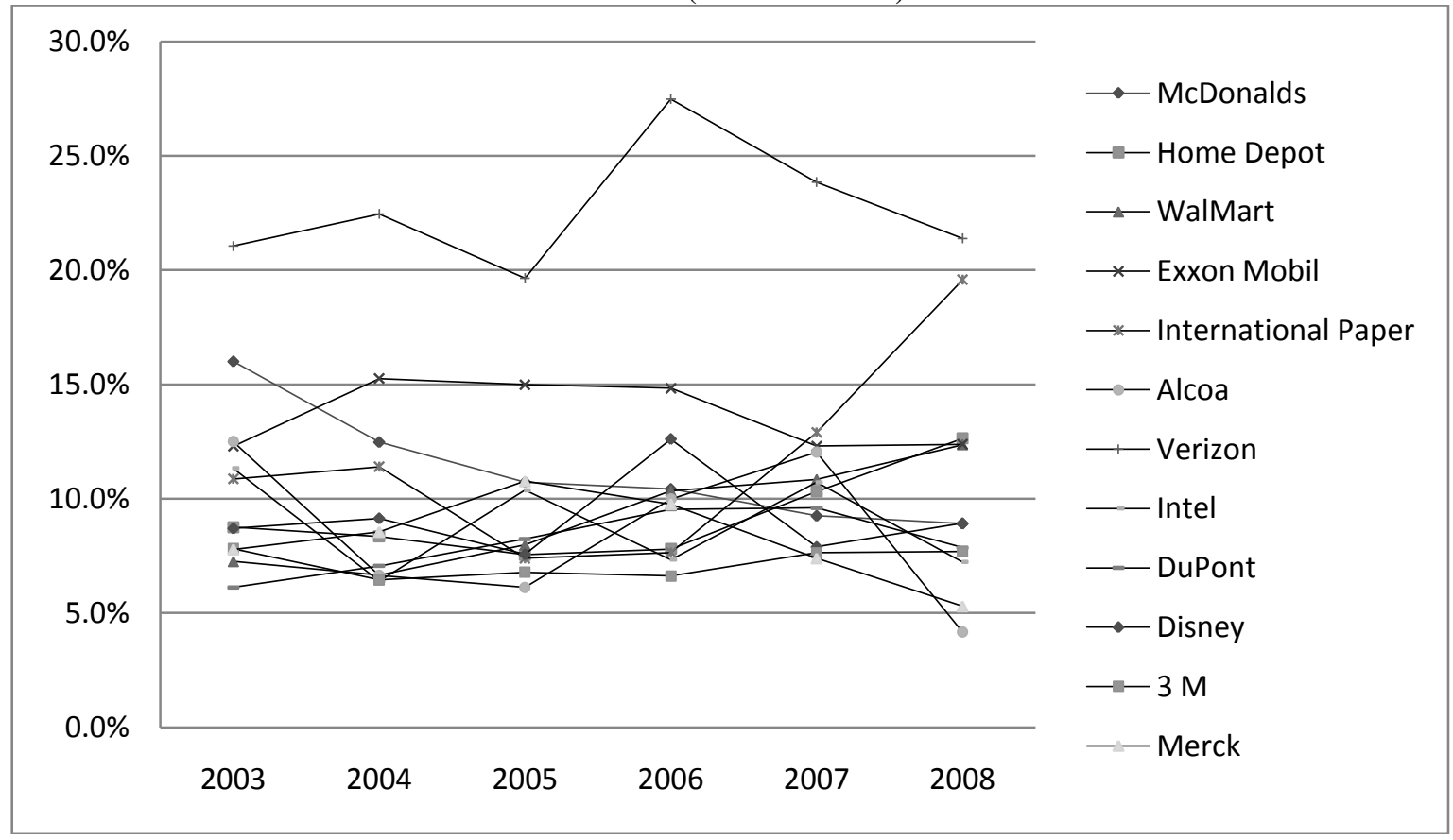

Figure 6: Operating Cash Flows Divided by Beginning of Period Stock Price for Firms with Fixed Assets $<15 \%$ of Total Assets (without outliers)

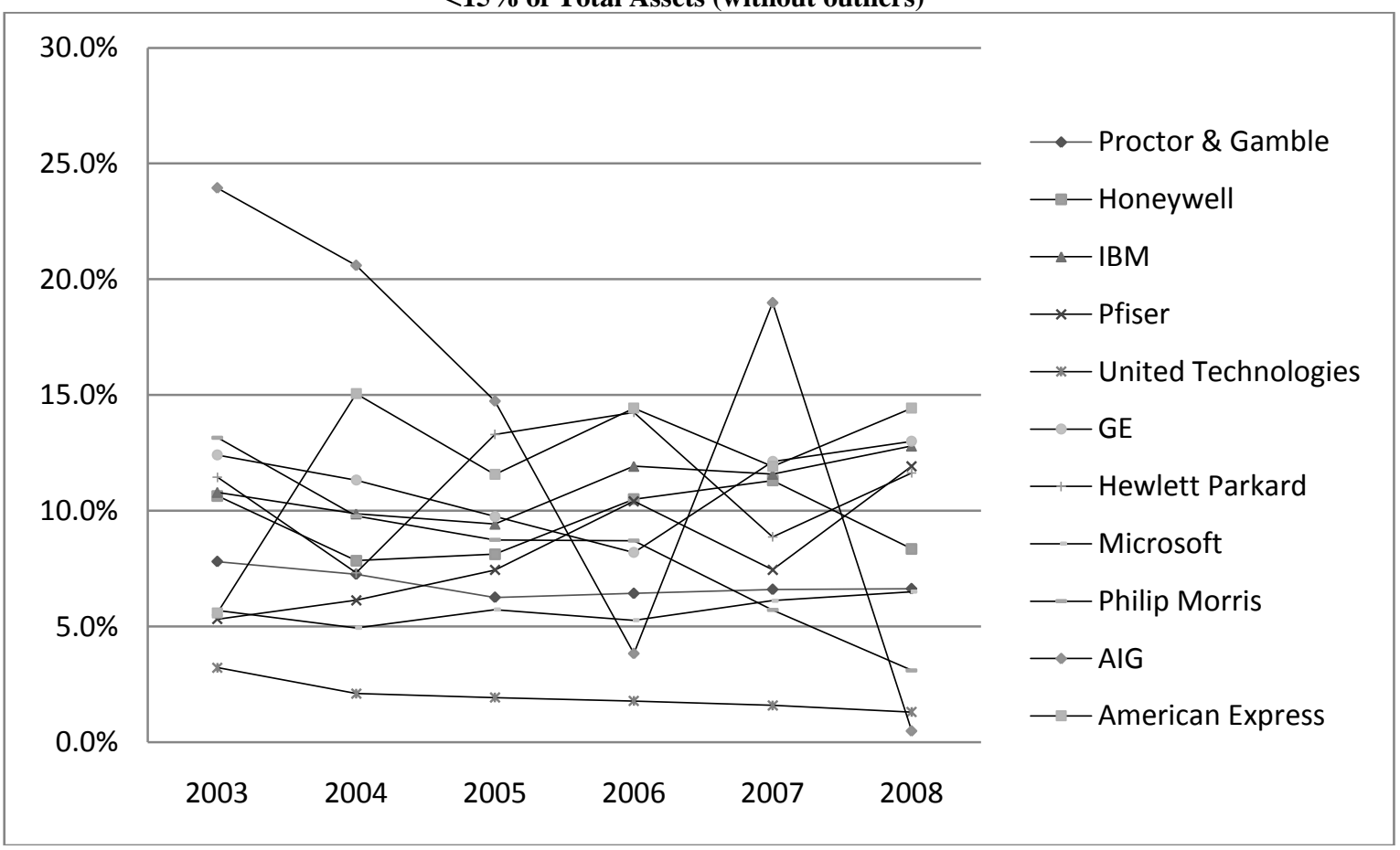




\section{RECOMMENDATIONS FOR FUTURE RESEARCH}

This is an exploratory study to attempt to measure IRR for publicly held companies. The observations in this study are based on a small sample of highly diversified firms. The study highlighted differences in net operating cash flows for firms with high capital intensity versus those firms that have low capital intensity but did not find the same degree of differences in cash flow based IRRs. Further research would expand the sample size significantly and examine cash flow IRR while controlling for differences in industry; capital intensity; and degrees of risk.

\section{AUTHOR INFORMATION}

Christine P. Andrews, D.B.A. is an Associate Professor of Accounting at Florida Gulf Coast University. She has worked as a CPA in public accounting, a cost analyst in manufacturing, and as an analyst in banking. She received her doctorate in accounting from Cleveland State University. Her current research interests include pedagogical issues and issues related to environmental accountability. She is a member of the AAA and the IMA.

Joseph Rue, Ph.D. Joseph C. Rue is a professor of accounting at Florida Gulf Coast University. He has previously taught at Syracuse University, Penn State and St Bonaventure University. He is CPA and received his PhD from the Pennsylvania State University in 1979. His research interest is in financial accounting. Recent publications have focused on accounting for stock options and deferred taxes.

Ara G. Volkan, Ph.D., CPA, is the Associate Dean of the Lutgert College of Business and the Chair of the Accounting Department at Florida Gulf Coast University. He joined the FGCU faculty in August 2004 as Eminent Scholar and Moorings Park Chair of Managerial Accounting. He received his doctorate in accounting from the University of Alabama in 1979. He holds a CPA certificate in Florida (1989). He is a member of the board of Directors Moorings Park, Inc. and its finance committee, the chair of the MPI Audit Committee, and the treasurer of Moorings Park community Health, Inc. in Naples, FL. Dr. Volkan is a member of the AICPA, FICPA, IMA AND AAA. He has authored numerous articles in academic and professional accounting journals and other business outlets.

\section{REFERENCES}

1. Ball, R. and Brown, P., An Empirical Evaluation of Accounting Income Numbers, Journal of Accounting Research, 6, Autumn, pp. 159-178, 1968.

2. Beaver, W.H., The Information Content of Annual Earnings Announcements, Empirical Research in Accounting: Selected Studies 1968 supplement to Vol. 6 of Journal of Accounting Research, pp. 67-92, 1968.

3. Fama, E.F., Efficient Capital Markets: A Review of Theory and Empirical Work, Journal of Finance, Vol. 25, pp. 383-417, 1970.

4. FASB Statement of Financial Accounting Concepts No. 1, Objectives of Financial Reporting by Business Enterprises. Stamford, Conn. FASB, 1978.

5. FASB Statement of Financial Accounting Concepts No. 7, Using Cash Flow Information and Present Value in Accounting Measurements. Stamford, Conn. FASB, 2000.

6. Ijiri, Y., Cash-Flow Accounting and Its Structure, Journal of Accounting, Auditing and Finance. Summer, pp. 331-348,1978.

7. $\quad$ Luckett. P.F., ARR vs. IRR: A Review and an Analysis, Journal of Business Finance \& Accounting, Vol. 11, No. 2, pp. 213-31, 1984.

8. Rue, J.C., Volkan, A.G. and Walker, W.H., Forecasting Cashflows and Internal Rate of Return, The Journal of Business Forecasting Methods \& Systems, Vol.6, Iss.3, pp.22-26, 1987.

9. Sprouse, R. The Importance of Earnings in the Conceptual Framework, Journal of Accountancy, Vol. 145, Iss. 1, pp. 64-71, 1978.

10. Steele, A., A Note on Estimating the Internal Rate of Return from Published Financial Statements, Journal of Business Finance \& Accounting, Vol. 13, No. 1, pp. 1-13, 1986.

11. Volkan, A.G. and Rue, J.C., Cash Recovery Rates and Profitability Analysis, The Woman CPA, Vol. 53, Iss. 1, pp. 16-18. 1991.

12. Yahoo! Finance retrieved on 8/27/2009 from: http://finance.yahoo.com/ 